\title{
Enterohepatic Helicobacter other than Helicobacter pylori
}

\author{
Beatriz Mateos-Muñoz ${ }^{1}$, Julio Pérez-de-la-Serna ${ }^{1}$, Antonio Ruiz-de-León ${ }^{1}$, Blanca Serrano-Falcón ${ }^{1}$, \\ Sergio Casabona-Francés ${ }^{1}$, Aurelio Velasco-Cerrudo ${ }^{2}$ and Enrique Rey-Díaz-Rubio ${ }^{1}$
}

Departments of ${ }^{1}$ Gastroenterology and ${ }^{2}$ Microbiology. Hospital Clínico San Carlos. Madrid, Spain

\begin{abstract}
The Helicobacter genus includes Gram negative bacteria which were originally considered to belong to the Campylobacter genus. They have been classified in a separate genus since 1989 because they have different biochemical characteristics, with more than 24 species having been identified and more still being studied.

H. pylori is the best known. It has an important etiopathogenic role in peptic ulcer disease and gastric cancer. Enterohepatic Helicobacters $(\mathrm{EHH})$ other than $H$. pylori colonize the bowel, biliary tree and liver of animals and human beings with pathogenic potential. The difficulties existing to correctly isolate these microorganisms limit the description of their true prevalence and of the diseases they cause. Many studies have tried to discover the different clinical implications of EHH. Diseases like chronic liver disease, autoimmune hepatitis, hepatocarcinoma, autoimmune hepatobiliary disease, biliary lithiasis, cholangiocarcinoma and gallbladder cancer, Meckel's diverticulum, acute appendicitis and inflammatory bowel disease have been related with different $\mathrm{EHH}$ species with different results, although their prevalence is greater than in healthy subjects. However, these data are currently not sufficient to draw definitive conclusions. Finally, the best known role of $\mathrm{EHH}$ in bowel disease is production of acute and chronic diarrhea pictures initially referred to as Campylobacter. H. pullorum has been identified in patients with acute gastroenteritis. The correct identification of $\mathrm{EHH}$ as producers of infectious gastroenteritis is found in its antibiotic susceptibility. It is generally macrolidesusceptible and quinolone-resistant.
\end{abstract}

Key words: Enterohepatic Helicobacter. Helicobacter pylori. Helicobacter pullorum. Helicobacter hepaticus. Helicobacter bilis. Chronic liver disease. Inflammatory bowel disease. Acute gastroenteritis.

\section{INTRODUCTION}

The Helicobacter genus includes curved or helical flagellated Gram negative bacilli. It was first considered to belong to the Campylobacter genus. However, since 1989, due to its different biochemical characteristics, it has been classified in a separate genus (Table I). Since then, more than 24 species have been identified and 31 more are still being studied (1,2) (Fig. 1).

Within this genus, the best known species is H. pylori, a pathogen of the upper gastrointestinal tract. This species plays an important role in peptic ulcer disease and gastric cancer. Its microbiological characterization, definition of diagnostic techniques and approach to specific therapeutic strategies may have been the most relevant discovery in gastric disease in recent times (3). However, although the gastric Helicobacters have been the most studied, they only account for one third of the entire genus. The remaining two-thirds correspond to the so-called enterohepatic Helicobacter (EHH) (4) because they predominantly colonize the bowel, biliary tree and the liver of animals (Table II) and human beings. These microorganisms are less known because they are difficult to culture from samples of these tissues and they require DNA hybridization and sequencing for their detection in most of the cases. Development of new laboratory techniques such as fatty acid profile, mass spectrometry and polymerase chain reaction (PCR) have made it possible to identify these germs more specifically. They are also Gram negative bacteria in spiral form that have a single polar flagellum. We could classify them into two groups, the first comprising flagellated bacteria which in turn have periplasmic cilia.

Mateos-Muñoz B, Pérez-de-la-Serna J, Ruiz-de-León A, SerranoFalcón B, Casabona-Francés S, Velasco-Cerrudo A, Rey-DíazRubio E. Enterohepatic Helicobacter other than Helicobacter pylori. Rev Esp Enferm Dig 2013;105:477-484.
Correspondence: Beatriz Mateos Muñoz. Department of Gastroenterology. Hospital Clínico San Carlos. C/ Doctor Martín Lagos, s/n. 28040 Madrid e-mail: bmateosm85@gmail.com
Received: $26-02-2012$

Accepted:29-05-2013 
The second subgroup lacks these and is structurally similar to the microorganisms of the Campylobacter genus (4). These similarities, together with the already-mentioned difficulties for their isolation, are an important limitation for the description of the pathogenic mechanism of these bacterias (5). The clinical interest of the EHHs comes from the growing number of publications of clinical cases as well as studies carried out on the involvement of these germs in liver, biliary and gastrointestinal diseases (Table III).

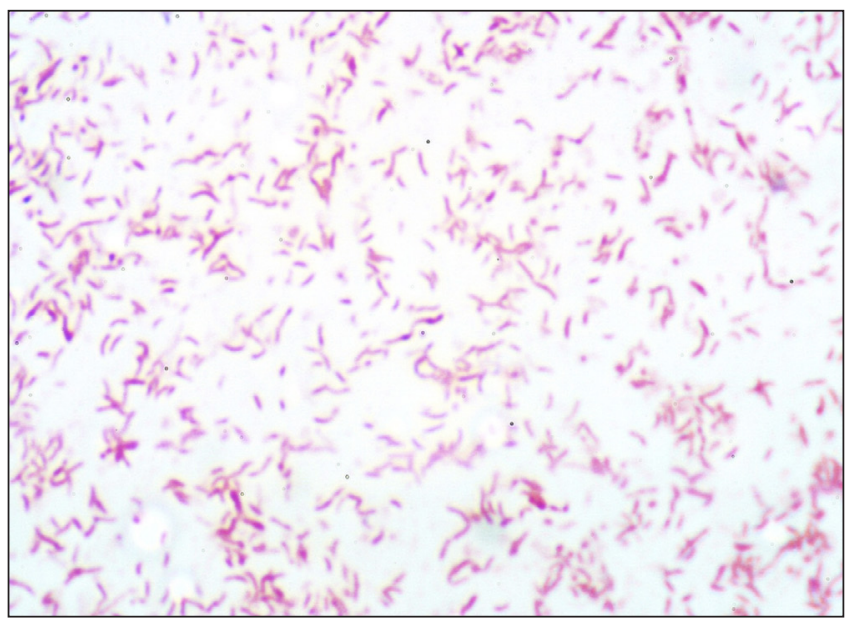

Fig. 1. Microphotograph of Helicobacter pullorum in a sample of stools of a male patient with acute gastroenteritis. Gram stain (1000x).

\section{EHH AND HEPATOBILIARY DISEASES}

Since the Helicobacter genus was identified, different bacteria capable of producing hepatobiliary diseases in animals have been characterized (6-24). H. hepaticus, $H$. rodentium, $H$. bilis and $H$. pullorum, among others, cause hepatitis and cholestasis pictures in mice and small mammals $(6-15,21)$. In this way, research regarding the pathogenic influence of these microorganisms in humans has been an important point of interest during the last decade.

The serology, culture of tissue samples and especially the specific polymerase chain reaction for the $16 \mathrm{~s}$ ribosomal RNA of Helicobacter are the techniques by which $H$. hepaticus, $H$. pullorum and $H$. bilis have been identified in humans with hepatobiliary disease (25).

\section{Chronic liver disease. Hepatic cirrhosis. Hepatitis C virus}

Detection of DNA of Helicobacter spp. in the liver parenchyma has potentiated the approach to the hypothesis on a possible relationship between EHH infection and chronic liver disease in cirrhotic stage. Siringo et al. (26) carried out a case-control study that compared seroprevalence of $H$. pylori in cirrhotic patients versus healthy blood donors. They obtained a positive serology in $76.5 \%$ of the cases and $41.8 \%$ of the controls ( $p<0.0005)$. However, the multivariate analysis revealed that these data were affected by other variables such as age and sex.

Table I. Enterohepatic Helicobacter. Microbiological characteristics. Similarities and differences with the Campylobacter genus (modified Schauer) (4)

\begin{tabular}{|c|c|c|c|c|c|c|}
\hline & Catalase & Urease & $\begin{array}{l}\text { Growth } \\
\text { at } 42^{\circ} \mathrm{C}\end{array}$ & $\begin{array}{l}\text { Number } \\
\text { of flagella }\end{array}$ & Covered flagella & Periplasmic cilia \\
\hline Campylobacter genus & + & - & + & Unipolar & + & - \\
\hline H. hepaticus & + & + & - & Bipolar & + & - \\
\hline H. cinaedi & + & - & - & Unipolar & + & - \\
\hline H. fennelliae & + & - & - & Bipolar & + & - \\
\hline H. canis & - & - & + & Bipolar & + & - \\
\hline H. parmetensis & + & - & + & Bipolar & + & - \\
\hline H. pullorum & + & - & + & Unipolar & - & - \\
\hline H. candensis & + & - & + & Uni/bip. & - & - \\
\hline H. rodentium & + & - & + & Bipolar & - & - \\
\hline H. typhlonicus & + & - & - & Bipolar & + & - \\
\hline H. cholecystus & + & - & + & Unipolar & + & - \\
\hline H. mesocricetorum & + & - & + & Bipolar & - & - \\
\hline H. muridarum & + & + & - & Bipolar & + & + \\
\hline H. rappini & - & + & + & Bipolar & + & + \\
\hline H. bilis & + & + & + & Bipolar & + & + \\
\hline H. trogontum & + & + & + & Bipolar & + & + \\
\hline
\end{tabular}


Table II. Enterohepatic Helicobacter: Isolations in animals and related pictures in them

\begin{tabular}{|c|c|c|c|}
\hline Species & Host & Isolation site & Disease \\
\hline H. pullorum (6-8) & Chicken and hen & Gastrointestinal tract and liver & $\begin{array}{l}\text { Gastroenteritis } \\
\text { Mild acute hepatitis }\end{array}$ \\
\hline H. hepaticus (9-12) & Mouse & Liver, bile duct and gall bladder & $\begin{array}{l}\text { Chronic hepatitis } \\
\text { Typhlitis. IBD } \\
\text { Hepatocellular tumors }\end{array}$ \\
\hline H. bilis (13-15) & Mouse and cat & Gastrointestinal tract and liver & $\begin{array}{l}\text { Chronic hepatitis } \\
\text { Typhlitis } \\
\text { Gastroenteritis }\end{array}$ \\
\hline H. rappini $(16,17)$ & Sheep, dogs and mice & $\begin{array}{l}\text { Liver, stomach } \\
\text { Ovine abortions }\end{array}$ & $\begin{array}{l}\text { Gastroenteritis } \\
\text { Abortions by hepatic necrosis }\end{array}$ \\
\hline H. cinaedi (18) & Hamster, Rhesus monkeys and dogs & Gastrointestinal tract & $\begin{array}{l}\text { Gastroenteritis } \\
\text { Bacteremia }\end{array}$ \\
\hline H. fenneliae (19) & Dogs and macaques & Gastrointestinal tract & Gastroenteritis \\
\hline H. canis (20) & Dogs, cats & Stools & Gastroenteritis \\
\hline H. rodentium $(21)$ & Mouse & Liver, gastrointestinal tract & $\begin{array}{l}\text { Acute cholangitis } \\
\text { Typhlitis }\end{array}$ \\
\hline H. muridarum (22) & Mouse & $\begin{array}{l}\text { Gastrointestinal tract and } \\
\text { stomach }\end{array}$ & $\begin{array}{l}\text { Gastroenteritis } \\
\text { Gastritis }\end{array}$ \\
\hline H. trogotum (23) & Rats & Bile ducts & Hepatitis \\
\hline H. aurati (24) & Hamster & $\begin{array}{l}\text { Gastrointestinal tract and } \\
\text { stomach }\end{array}$ & $\begin{array}{l}\text { Chronic gastritis } \\
\text { Intestinal metaplasia } \\
\text { Typhlitis }\end{array}$ \\
\hline
\end{tabular}

Table III. Helicobacter related with different diseases in humans

\begin{tabular}{|c|c|c|c|}
\hline Species & Hepatobiliary disease & Pancreatic disease & Bowel disease \\
\hline H. pylori & $\begin{array}{l}\text { Chronic liver disease }(26,27) \\
\text { HCC }(30-40)\end{array}$ & Pancreatic tumors (61-66) & $\begin{array}{l}\text { Meckel's diverticulum }(77,78) \\
\text { Acute appendicitis }(79)\end{array}$ \\
\hline H. hepaticus & $\begin{array}{l}\text { Chronic liver disease }(27) \\
\text { HCC }(30-40) \\
\text { PSC and PBC }(45) \\
\text { Cholelitiasis }(48,50,52)\end{array}$ & & \\
\hline H. pullorum & $\begin{array}{l}\text { Liver disease by HCV (29) } \\
\text { PSC and PBC (45) } \\
\text { Cholelitiasis (49) }\end{array}$ & & $\begin{array}{l}\text { Meckel's diverticulum (76) } \\
\text { Acute appendicitis }(76) \\
\text { IBD }(81-84) \\
\text { Acute gastroenteritis }(74,86) \\
\text { Post-infectious irritable bowel syndrome (74) }\end{array}$ \\
\hline H. bilis & $\begin{array}{l}\text { Liver disease by HCV }(29) \\
\text { HCC }(30-39) \\
\text { PSC and PBC }(45) \\
\text { Cholelitiasis }(47,48,51) \\
\text { Cholangiocarcinoma }(47,48,51) \\
\text { Acute and chronic cholecistitis }(51)\end{array}$ & & \\
\hline H. ganmani & $\begin{array}{l}\text { Cholelitiasis (51) } \\
\text { Cholangiocarcinoma (51) } \\
\text { Acute and chronic cholecystitis (51) }\end{array}$ & & \\
\hline H. cinaedi & & & $\begin{array}{l}\text { Proctitis and proctocolitis (75) } \\
\text { Enteritis (4) }\end{array}$ \\
\hline H. rappini & & & Chronic diarrhea (75) \\
\hline H. fennelliae & & & $\begin{array}{l}\text { Proctitis and proctocolitis (75) } \\
\text { Enteritis (4) }\end{array}$ \\
\hline
\end{tabular}


Because of the possibility that the serology of $H$. pylori could have a cross-reactivity with IgG of other bacteria of the genus, Nilsson et al. (27) studied the seroprevalence of $H$. pylori and $H$. hepaticus in 144 patients with chronic liver disease of different etiologies. They found a similar seroprevalence of both species (44vs. $39 \%$ ), which is also similar to that existing in the general population (48 vs. $46 \%)$. At the same time, they discovered a specific immune reaction against $H$. hepaticus, with greater concentration of antibodies in $26 \%$ of the cases. However, this higher titer did not seem to be related to baseline hepatic disease.

A possible relationship between EHH and hepatitis $\mathrm{C}$ virus (HCV) has also been proposed. In this sense, Ponzetto et al. (28) determined that the seroprevalence of Helicobacter spp. in cirrhotic patients with positive HCV is $77 \%$, while it is about $59 \%$ in healthy controls ( $<<$ 0.004). Lönngren et al. (29) described seroprevalences of $18 \%$ for $\mathrm{H}$. pullorum and $8 \%$ for $\mathrm{H}$. bilis in positive $\mathrm{HCV}$ patients versus $0 \%$ in healthy subjects. The possibility that $\mathrm{EHH}$ may contribute to progression of chronic liver disease due to this virus has been analyzed in a stratified way, classifying the study subjects into four groups: Healthy patients, patients with chronic hepatitis, cirrhotic patients and patients with hepatocellular carcinoma (HCC). Presence of Helicobacter spp. DNA in each one of the groups was studied. A total of $68 \%$ of the patients with hepatic cirrhosis and $90 \%$ of those with HCC had DNA of this bacteria genus compared to $4.2 \%$ of patients with chronic hepatitis and $3.5 \%$ of the controls, which means a statistically significant difference regarding the pooled analysis of the data from the first two versus the latter two groups $(p<0.0001)(30)$. However, unfortunately the results are not very conclusive since these studies have been performed with a small number of patients and have potential confounding factors such as the course, per se, of chronic viral liver disease. Thus, their conclusions must be considered with caution until new studies are published.

\section{Hepatocarcinoma}

Based on the known gastric carcinogenesis produced by $H$. pylori and motivated by the good therapeutic response to it, the possibility has been proposed that EHH would have a role in the appearance of HCC. There are 10 case-control studies on this association (30-39). All of them, except one (39), describe a significantly greater presence of EHH DNA in the liver tissue of patients with HCC than in healthy subjects (40). Although these results are remarkable, the heterogeneity of the samples and the study design as well as the presence of hepatotropic virus infection prevent the acquisition of definitive conclusions. Different hypotheses have been postulated on the mechanisms of carcinogenesis that the EHH could have, whether indirectly by the production of chronic inflammatory cytokine that contributes to cellular damage (41), or directly by DNAsa activity of cytolytic toxins that are produced by these germs (42). On the other hand, it should be stated that the fact that DNA of these microorganisms can be detected but not isolated in a culture casts some doubts on the existence of a real infection. However, the results indicate that they are a more than sufficient motivation to continue this line of research.

\section{Autoimmune hepatobiliary disease}

In hepatic biopsies of patients with primary sclerosing cholangitis (PSC) and primary biliary cirrhosis (PBC), both the presence of EHH DNA (43) and bacteria of this genus in Kupffer cells have been detected (44). Based on these results, Nilsson et al. (45) carried out a study of the seroprevalence of $H$. pullorum, $H$. bilis and $H$. hepaticus in patients with PSC, finding that each one of them were at $38 \%, 22 \%, 25 \%$, respectively and that this prevalence was significantly greater than in the healthy controls $(\mathrm{p}<$ $0.05 ; \mathrm{p}<0.001$ and $\mathrm{p}<0.001$, respectively) in every case. Equally, considering patients with autoimmune hepatitis as cases, a seroprevalence of $30 \%$ was obtained for $\mathrm{H}$. pullorum, $22 \%$ for $H$. bilis and $12 \%$ for $H$. hepaticus, all being statistically significant ( $\mathrm{p}<0.001$ in all of them) compared to the controls. In the cases with positive $\mathrm{EHH}$, there was a statistically significant tendency towards higher levels of alkaline phosphatase and lengthening of prothrombin activity time than in healthy subjects $(\mathrm{p}<0.0001$ and $\mathrm{p}<$ 0.0003 ), but not in the total bilirubin (43). Sample size of these studies is small so that the results are not conclusive. However, considering that autoimmune diseases are caused by genetic as well as environmental factors, it is proposed that EHH could play an important role in these mechanisms on the hepatic level that still must somehow be elucidated.

\section{Biliary disease}

Helicobacter spp. has been isolated from the bile of subjects with different diseases as well as from of healthy subjects (46). In these cases, the possibility of ascending colonization from the duodenum to the bile ducts and gallbladder by these microorganisms is considered. Its survival in such an inhospitable environment as the bile could be favored by the peptidase enzymes that these germs have (25). The role that these bacteria could play in the lithogenesis has been investigated in different projects, in which the presence of $H$. bilis $(47,48), H$. pullorum (49) H. hepaticus $(48,50)$ and $H$. ganmani $(51)$ has been studied with different techniques (PCR, serology and culture, among others) and in different samples (blood, bile, gallbladder) in patients with cholelithiasis and in control subjects. The results, although very heterogeneous, show greater prevalence of lithiasis in EHH infected patients in every case. Specifically, $H$. hepaticus infection triples 
the possibility of having cholelithiasis (OR 3.13, $95 \%$ CI 1.20-8.19) (52).

At the same time, it was observed that greater bile acidity meant greater survival of these species, so that conditions such as cholecystitis and obstructive biliary disease in which the biliary $\mathrm{pH}$ decreases would favor secondary bacterial overgrowth and would collaborate in the infection of the biliary system (25). In this regards, several studies have been made in an attempt to know the role of EHH in acute and chronic cholecystitis $(15,51,53-56)$. The results obtained are very heterogeneous, with a prevalence of EHH in cholecystectomy specimens by these conditions of $39 \%$ in Chile (15), while in Germany it is $2 \%$ (51). These discrepancies could be based on the geographic differences with different prevalences of EHH, although the differences in the diagnostic methods used and in the heterogeneity of the study design should also be stressed.

There is also a hypothesis that relates EHH with cholangiocarcinoma and gallbladder cancer. In this way, already previously-mentioned studies $(47,48,51,53,54)$ and others (57-60) evaluated the presence of Helicobacter DNA by PCR in cholecystectomy samples. The results, as in the previous point, were very diverse so that it is not possible to draw definitive conclusions.

\section{EHH AND PANCREATIC DISEASE}

In recent years, there have been different hypotheses on the participation of bacterias of the Helicobacter genus in pancreatic disease. The most important ones mention its possible oncogenic role in pancreatic cancer. Several studies are found on seroprevalence of $H$. pylori in patients with pancreatic tumors (61-66) that show a significant relationship with an OR of 1,379 (95\% CI 1,083$1,796)$ regarding the controls. However, there are only two projects that study this relationship using molecular techniques $(67,68)$ : Jenawski et al. (67) that analyzes the presence of Helicobacter spp. DNA in pancreatic juice and tissue of patients with pancreatic adenocarcinoma without obtaining a positive result. In addition, Nilsson et al. (68) also studied this relationship by PCR, demonstrating the existence of DNA of these microorganisms in tissue samples: In $75 \%$ of the cases of exocrine tumors, in $57 \%$ of the neuroendocrines and in $60 \%$ of the samples obtained from patients with multiple neoplasia syndrome. Different oncogenic mechanisms by which Helicobacter could produce pancreatic cancer have been postulated, although none have been molecularly demonstrated (69). It should also be pointed out that as in the case of hepatobilary disease, the Helicobacter genus has been related with different autoimmune conditions. Autoimmune pancreatitis is a condition that has been linked to these bacteria but there are no studies with results that support it (68). However, there are different pathogenic hypotheses that principally collect cross-reactivity mechanisms (70).

\section{EHH AND INTESTINAL DISEASE}

Multiple species of the Helicobacter genus have been isolated in the gastrointestinal tract in both asymptomatic animals and in those with gastritis or enteritis. Thus, $H$. pullorum, $H$ cinaedi, $H$. canis, $H$. bilis and $H$. muridarum have been described as responsible for this type of condition in poultry and domestic animals (4). In humans, these microorganisms have been detected by PCR in stools of patients with acute gastroenteritis $(8,71-75)$ and have been related with cases of Meckel's diverticulum (76-78), acute appendicitis (79) and with inflammatory bowel disease (80-85).

\section{Meckel’s diverticulum}

Based on the fact that it is not uncommon to find ectopic gastric mucosa in Meckel's diverticulum, Bemelman et al. (77) and Tuzum et al. (78) studied the possibility that this mucosa would be infected by $H$. pylori and that this would collaborate in the clinical manifestations of the diverticulum. These authors investigated the presence of the microorganism by microscope and PCR of the surgical specimens, respectively, but the results were not very encouraging. Bemelman et al. (77) obtained 1 case out of 18 diverticula with positive ectopic gastric mucosa for H. pylori and Tuzun et al. (78) none out of 12 cases. In 2011, Karagin et al. published a study on the presence of EHH in patients with Meckel's diverticulum (76). They found DNA of $H$. pullorum by PCR in $3 \%$ of the cases. However, they were not able to demonstrate the presence of the germ by immunohistochemistry study.

\section{Acute appendicitis}

The role of bacterias of the Helicobacter genus in acute appendicitis has also been discussed. There are few studies published about this. Paredes et al. (79) conducted a case-control study analyzing the presence of $H$. pylori antigen in stools and in the culture of the appendectomy samples. They observed antigens in stools in $35 \%$ of patients, finding that $71.4 \%$ of the cultures were also positive. However, this was not statistically significant in comparison with the controls. Karagin et al. (76) analyzed the presence of EHH in similar samples by PCR but none of the cases were positive.

\section{Inflammatory bowel disease}

Ulcerative colitis and Crohn's disease are two conditions for which an effort has been made to relate them with EHH. Due to the participation of the genetic and environmental factors, among them microbiological ones, in the pathogenesis of inflammatory bowel disease (IBD), the 
possible influence of these microorganisms in its development was postulated. It had been demonstrated in the laboratory that bacteria of the Helicobacter genus would produce IBD in immunodepressed mice (85), so that its presence in human patients suffering IBD was also studied. The results of the studies on this relation are heterogeneous. Thus, in the earliest studies on the subject, it was not possible to detect DNA of any EHH in colonic mucosa samples (80). However, more recent studies have found a statistically significant relation between EHH and IBD $(83,84)$. Laharie et al. (81) analyzed the presence of DNA of these bacteria by PCR in a total of 44 samples obtained by colonoscopy in patients with Crohn's disease and healthy controls. They defined a prevalence of $12 \%$ in the cases compared to $4 \%$ in the controls. In patients with ulcerative colitis, in a study with a similar design, Thomson et al. (82) found a prevalence of $61 \%$ in patients compared to $10 \%$ in healthy controls. However, these results must be treated with caution because of the same sample size of the studies published and especially the existing difficulty to obtain homogeneous samples of patients.

\section{Acute infectious gastroenteritis}

Finally, perhaps the best known role of EHH in bowel disease is the production of acute and chronic diarrhea. Until a few years ago, enteritis caused by these microorganisms were included within those caused by the Campylobacter genus due to their microscopic similarity (86). However, the development of new laboratory techniques as the fatty acid profile (87), mass spectrometry and the PCR (8) have made it possible to identify the germs more specifically. As these techniques become more generalized, more will become known on the real prevalence of these bacteria in the population (8). EHHs have been isolated in the digestive tract of poultry and domestic animals $(88,89)$ and $H$. pullorum was designated as a separate species, on the basis of sequencing of the $16 \mathrm{~S}$ rRNA gene (7). H. pullorum has been isolated in cecal samples from broiler chickens with subclinical infection, in the liver and intestinal content of laying hens with vibrionic hepatitis and in human beings with gastroenteritis $(7,8)$. Furthermore, elevation of hepatic enzymes and hepatomegaly was observed in one patient with diarrhea (73). It has been demonstrated in vitro that $H$. pullorum survives more than $36 \mathrm{~h}$ in water (90). Therefore, although the epidemiological chain has not been clearly defined (72), there appears to be a basis to consider food borne transmission of the gastroenteritis of $H$. pullorum as occurs with the Campylobacter species (4). Generally, they cause watery diarrhea with rectal bleeding in which it is believed that a cytotoxic toxin that has been isolated in certain cases of H. pullorum diarrhea could be involved, although not in other EHHs (86). In our center, where Helicobacter pullo- rum is being investigated systematically since April 2010, 9 cases that affected patients with a wide age spectrum have been identified (74). The clinical picture of watery diarrhea was accompanied by rectal bleeding in $33 \%$ of the cases, abdominal pain in $55 \%$ and weight loss in $44 \%$. In the evolution, $55 \%$ of the patients reported alternating bowel habit and existence of periods of abdominal pain. Antimicrobial susceptibility of the strains was quite uniform, all of them susceptible to macrolides (erythromycin and azithromycin) and to amoxicillin-clavulanate, while $80 \%$ were quinolone-resistant (ciprofloxacin and levofloxacin).

Two cases of chronic diarrhea apparently caused by $H$. rappini (75) have been described. One of them was associated to fever and headache, with background of contact with infected domestic animals and another without fever or known contact with animals. Both responded effectively to erythromycin. Other species of Helicobacter such as H. cinaedi (from Latin for "of a homosexual") or H. fennelliae were isolated from rectal samples of male homosexuals and also in asymptomatic individuals and individuals with proctitis, proctocolitis, and enteritis. Although $H$. cinaedi has been described as a cause of acute diarrhea in otherwise healthy subjects, it more often causes bacteremia in patients with immunodeficiency (4).

It could be noted that the greatest relevance of the correct identification of $\mathrm{EHH}$ as producers of infectious gastroenteritis is found in the antibiotic susceptibility of these microorganisms, since they generally present resistance to quinolones ( $85 \%$ for ciprofloxacin, $75 \%$ for levofloxacin) and they have a bimodal behavior regarding tetracyclines (resistant in $76 \%$ of the cases) and macrolides (susceptible in $85 \%$ ) (91). Furthermore, as has been stated, EHH should be investigated in cases of chronic diarrhea and, in our opinion, in patients with diarrhea and symptoms consistent with irritable bowel syndrome of possible post-infectious etiology (74).

\section{REFERENCES}

1. Fox JG. The non-H pylori helicobacters: Their expanding role in gastrointestinal and systemic diseases. Gut 2002;50:273-83.

2. Hua JS, Zheng PY, Bow H. Species differentiation and identification in the genus of Helicobacter. World J Gastroenterol 1999;5:7-9.

3. Bohr U, Franceschi F, Roccarina D, Gasbarrini A. Extragastric manifestations of Helicobacter pylori infection-Other Helicobacters. Helicobacter 2007; 12:45-53.

4. Schauer DB. Enterohepatic Helicobacter Species. In: Mobley HLT, Mendz GL, Hazell SL, editors. Helicobacter pylori: Physiology and Genetics. Washington (DC): ASM Press; 2001. Chapter 43. Available from:http://www.ncbi.nlm.nih.gov/books/NBK2448/).

5. Solnick E, Schauer DB. Emergence of diverse Helicobacter species. Clin Microbiol Rev 2001;14:70-88.

6. Atabay HI, Corry JE, On SL. Identification of unusual Campylobacter-like isolates from poultry products as Helicobacter pullorum. J Appl Microbiol 1998;84:1017-24.

7. Stanley J, Linton D, Burnens AP, Dewhirst FE, On SL, Porter A, et al. Helicobacter pullorum sp. nov.-genotype and phenotype of a new species isolated from poultry and from human patients with gastroenteritis. Microbiology 1994;140:3441-9. 
8. Steinbrueckner B, Haerter G, Pelz K, Weiner S, Rump JA, Deissler W, et al. Isolation of Helicobacter pullorum from patients with enteritis. Scand J Infect Dis 1997;29:315-8.

9. Fox JG, Yan L, Shames B, Campbell J, Murphy JC, Li X. Persistent hepatitis and enterocolitis in germ-free mice infected with Helicobacter hepaticus. Infect Immun 1996;64:3673-81.

10. Ward JM, Anver MR, Haines DC, Benveniste RE. Chronic active hepatitis in mice caused by Helicobacter hepaticus. Am J Pathol 1994;145:959-68.

11. Dieleman LA, Arends A, Tonkonogy SL, Goerres MS, Craft DW, Grenther W, et al. Helicobacter hepaticus does not induce or potentiate colitis in interleukin-10-deficient mice. Infect Immun 2000;68:5107-13.

12. Sellon RK, Tonkonogy S, Schultz M, Dieleman LA, Grenther W, Balish E, et al. Resident enteric bacteria are necessary for development of spontaneous colitis and immune system activation in interleukin-10-deficient mice. Infect Immun 1998;66:5224-31.

13. Fox JG, Yan LL, Dewhirst FE, Paster BJ, Shames B, Murphy JC, et al. Helicobacter bilis sp. nov., a novel Helicobacter species isolated from bile, livers, and intestines of aged, inbred mice. J Clin Microbiol 1995;33:445-54.

14. Shomer NH, Dangler CA, Marini RP, Fox JG. Helicobacter bilis/Helicobacter rodentium co-infection associated with diarrhea in a colony of scid mice. Lab Anim Sci 1998;48:455-9.

15. Fox JG, Dewhirst FE, Shen Z Feng Y, Taylor NS, Paster BJ, et al. Hepatic Helicobacter species identified in bile and gallbladder tissue from Chileans with chronic cholecystitis. Gastroenterology 1998:114:755-63.

16. Crawshaw TR, Fuller HE. Flexispira rappini suspected in ovine abortion. Vet Rec 1994;134:507.

17. Eaton KA, Dewhirst FE, Paster BJ, Tzellas N, Coleman BE, Paola J, et al. Prevalence and varieties of Helicobacter species in dogs from random sources and pet dogs: Animal and public health implications. J Clin Microbiol 1996;34:3165-70.

18. Kiehlbauch JA, Brenner DJ, Cameron DN, Steigerwalt AG, Makowski $\mathrm{JM}, \mathrm{Baker} \mathrm{CN}$, et al. Genotypic and phenotypic characterization of Helicobacter cinaedi and Helicobacter fennelliae strains isolated from humans and animals. J Clin Microbiol 1995;33:2940-47.

19. Totten PA, Fennell CL, Tenover FC, Wezenberg JM, Perine PL, Stamm WE, et al. Campylobacter cinaedi (sp. nov.) and Campylobacter fennelliae (sp. nov.): Two new Campylobacter species associated with enteric disease in homosexual men. J Infect Dis 1985;151:131-9.

20. Chien CC, Taylor NS, Ge Z, Schauer DB, Young VB, Fox JG. Identification of cdtB homologues and cytolethal distending toxin activity in enterohepatic Helicobacter spp. J Med Microbiol 2000;49:525-34.

21. Shen Z, Fox JG, Dewhirst FE, Paster BJ, Foltz CJ, Yan L, et al. Helicobacter rodentium sp. nov., a urease-negative Helicobacter species isolated from laboratory mice. Int J Syst Bacteriol 1997;47:627-34.

22. Phillips MW, Lee A. Isolation and characterization of a spiral bacterium from the crypts of rodent gastrointestinal tracts. Appl. Environ. Microbiol 1983;45:675-83.

23. Foster JR. Bacterial infection of the common bile duct in chronic fascioliasis in the rat. J Comp Med 1984;94:175-81.

24. Patterson MM, Schrenzel MD, Feng Y, Xu S, Dewhirst FE, Paster BJ, et al. Helicobacter aurati sp. nov., a urease-positive helicobacter species cultured from gastrointestinal tissues of Syrian hamsters. J Clin Microbiol 2000;38:3722-8.

25. Leong RW, Sung J. Review article: Helicobacter species and hepatobiliary diseases. Aliment Pharmacol Ther 2002;16:1017-45.

26. Siringo S, Vaira D, Menegatti M, Fiscaglia F, Soccorsa S, Gaetani M, et al. High prevalence of Helicobacter pylori in liver cirrhosis: Relationship with clinical and endoscopic features and the risk of peptic ulcer. Dig Dis Sci 1997;42:2024-30.

27. Nilsson I, Lindgren S, Eriksson S, Wadström T. Serum antibodies to Helicobacter hepaticus and Helicobacter pylori in patients with chronic liver disease. Gut 2000;46:410-4.

28. Ponzetto A, Pellicano R, Leone N, Cutufia M, Turrini F, Grigioni WF, et al. Helicobacter infection and cirhosis in hepatitis $\mathrm{C}$ virus carriage: Is it an innocent bystander or a troublemarker? Med Hypotheses 2000;54:275-7.

29. Lönngren V, Nilsson I, Verbaan H, Wadström T, Ljungh A. High levels of serum antibodies to cell surface proteins of Helicobacter pullorum and Helicobacter pylori in hepatitis C virus-infected patients. Scand $\mathrm{J}$ Gastroenterol 2009;44:505-6.

30. Rocha M, Avenaud P, Ménard A, Le Bail B, Balabaud C, Bioulac-Sage $\mathrm{P}$, et al. Association of Helicobacter species with hepatitis $\mathrm{C}$ cirrhosis with or without hepatocellular carcinoma. Gut 2005;54:396-401.

31. Pellicano R, Mazzaferro V, Grigioni WF, Cutufia MA, Fagoonee S, Silengo $\mathrm{L}$, et al. Helicobacter species sequences in liver samples from patients with and without hepatocellular carcinoma. World J Gastroenterol 2004;10:598-601.

32. Ito K, Nakamura M, Toda G, Negishi M, Torii A, Ohno T. Potential role of Helicobacter pylori in hepatocarcinogenesis. Int J Mol Med 2004;13:221-7.

33. Dore MP, Realdi G, Mura D, Graham DY, Sepulveda AR. Helicobacter infection in patients with HCV-related chronic hepatitis, cirrhosis, and hepatocellular carcinoma. Dig Dis Sci 2002;47:1638-43.

34. Avenaud P, Marais A, Monteiro L, Le Bail B, Bioulac P, Balabaud C, et al. Detection of Helicobacter species in the liver of patients with and without primary liver carcinoma. Cancer 2000;89:1431-9.

35. Nilsson HO, Mulchandani R, Tranberg KG, Stenram U, Wadstrom T. Helicobacter species identified in liver from patients with cholangiocarcinoma and hepatocellular carcinoma. Gastroenterology 2001;120:323-4.

36. Zhang SQ, Bao Y, Zu MH. The correlation between Helicobacter infection and hepatocellular carcinoma. Zhongguo Zhongliu Linchuang 2004;31:761-4.

37. Huang Y, Fan XG, Zhou JH. Immunohistochemistry of Helicobacter pylori in primary liver carcinoma tissues. Zhong Nan Da Xue Xue Bao Yi Xue Ban 2004;29:15-7.

38. Li N, Zhang SH, Xuan SY, Qiang X. Study on Helicobacter infection in liver tissue from hepatocellular carcinoma. Zhonghua Liusingbingxue Zazhi 2006;27:894-6.

39. Coppola N, De Stefano G, Marrocco C, Scarano F, Scolastico C, Tarantino L, et al. Helicobacter spp. and liver diseases. Infez Med 2003;11:201-7.

40. Pellicano R, Méard A, Rizzetto M, Mégraud F. Helicobacter species and liver diseases: Association or causation? Lancet Infect Dis 2008;8:254-60.

41. Ballwill F, Mantovani A. Inflammation and cancer: Back to Virchow? Lancet 2001;357:539-45.

42. Thomas DL, Astemborski J, Rai RM, Anania FA, Schaeffer M, Galai $\mathrm{N}$, et al. The natural history of hepatitis $\mathrm{C}$ virus infection. Host, viral and environmental factors. JAMA 2000;284:450-6.

43. Nilsson H, Taneera J, Castedal M, Glatz E, Olsson R, Wadström T. Identification of Helicobacter pylori and other Helicobacter species by PCR, hybridization, and partial DNA sequencing in human liver samples from patients with primary sclerosing cholangitis or primary biliary cirrhosis. J Clin Microbiol 2000;38:410-4.

44. Wadström T, Ljungh A, Willen R. Primary biliary cirrhosis and primary sclerosing cholangitis are of infectious origin! Gut 2001;49:454.

45. Nilsson I, Kornilovska I, Lindgren S, Ljungh A, Wadström T. Increased prevalence of seropositivity for non-gastric Helicobacter species in patients with autoimmune liver disease. J Med Microbiol 2003;52:949-53.

46. Hamada T, Yokota K, Ayada K, Hirai K, Kamada T, Haruma K, et al. Detection of Helicobacter hepaticus in Human bile samples of patients with biliary disease. Helicobacter 2009;14:545-51.

47. Matsukura N, Yokomuro S, Yamada S, Tajiri T, Sundo T, Chayama K, et al. Association between Helicobacter bilis in bile and biliary tract malignancies: $\mathrm{H}$. bilis in bile from Japanese and Thai patients with benign and malignant diseases in the biliary tract. Jpn J Cancer Res 2002;93:842-7.

48. Kobayashi T, Harada K, Miwa K, Nakanuma Y. Helicobacter genus DNA fragments are commonly detectable in bile from patients with extrahepatic biliar diseases and associated with their pathogenesis. Dig Dis Sci 2005;39:862-7.

49. Karagin PH, Stenram U, Wadström T, Ljungh A. Helicobacter species and common gut bacterial DNA in gallbladder with cholecystitis. World J Gastroenterol 2010;16:4817-22.

50. Shimoyama T, Takahashi R, Abe D, Mizuki I, Endo T, Fukuda S. Serological analysis of Helicobacter hepaticus infection in patients with biliary and pancreatic diseases. J Gastroenterol Hepatol 2010;25(Supl. 1):886-9. 
51. Bohr UR, Kuester D, Meyer F, Wex T, Stillert M, Csepregi A, et al. Low prevalence of Helicobacteraceae in gall-stone disease and gall-bladder carcinoma in German population. Clin Microbil Infect 2007; 13:525-31.

52. Zhou Di, Zhang Y, Gong W, Mohamed SO, Ogbomo H, Wang X, et al. Are Helicobacter Pylori and other species infection associated with human biliary lithiasis? A meta-analysis. PLoS ONE 6(11): e27390. Doi:10.1371/journal.pone.0027390.

53. Murata H, Tsuji S, Tsuji M, Fu Hy, Tanimura H, Tsujimoto M, et al. Helicobacter bilis infection in biliary tract cancer. Aliment Pharmacol Ther 2004;(20 Supl. 1):90-4.

54. Fukuda K, Kuroki T, Tajima Y, Tsuneoka N, Kitajima T, Matsuzaki S, et al. Comparative analysis of Helicobacter DNAs and biliary pathology in patients with and without hepatobiliary cancer. Carcinogenesis 2002;23:1927-31.

55. Chen DF, Hu I, Yi P, Liu WW, Fang DC, Cao H. Helicobacter pylori exist in the gallbladder mucosa of patients with chronic cholecystitis. World J Gastroenterol 2007;13:1608-11.

56. Apostolov E, Al-Soud WA, Nilsson I, Kornikovska I, Usenko V, Lyzogubov V, et al. Helicobacter pylori and other Helicobacter species in gallbladder and liver of patients with chronic cholecystitis is detected by immunological and molecular methods. Scand J Gastroenterol 2005;40:96-102.

57. Roe IH, Kim JT, Lee HS, Lee JH. Detection of Helicobacter DNA in bile from bile duct diseases. J Korean Med Sci 1999;14:182-6.

58. Bulajic M, Maisonneuve P, Schneider-Brachert W, Muller P, Reischi $\mathrm{U}$, Stimec B, et al. Helicobacter pylori and the risk of benign and malignant biliary tract disease. Cancer 2002;95:1946-53.

59. Fallone CA, Tran S, Semret M, Discepola F, Behr M, et al. Helicobacter DNA in bile correlation with hepato-biliary diseases. Aliment Pharmacol Ther 2003;132:453-8.

60. Pradhan SB, Dali S. Relation between gallbladder neoplasm and Helicobacter hepaticus infection. Kathmandu Univ Med J 2004;2:331-5.

61. Raderer M, Wrba F, Kornek G, Maca T, Koller DY, Weinlaender G, et al. Association between Helicobacter pylori infection and pancreatic cancer. Oncology 1998;55:16-9.

62. Stolzenber-Salomon RZ, Blaser MJ, Limburg PJ, Perez-Perez G, Taylor PR, Virtamo J et al. Helicobacter pylori seropositivity as a risk factor for pancreatic cancer. J Narl Cancer Inst 2001;93:937-41.

63. Lindkvist B, Johansen D, Borgström A, Manjer J. A prospective study of Helicobacter pylori in relation to the risk for pancreatic cancer. BMC Cancer 2008;8:321.

64. De Martel C, Losa AE, Friedman GD, Vogelman JH, Orentreich $\mathrm{N}$, Stolzenber-Salomon RZ, et al. Helicobacter pylori infection and development of pancreatic cancer. Cancer Epidemiol Biomarkers Prev 2008:17:1188-94.

65. Risch HA, Yu H, Lu L, Kidd MS. ABO blood group. Helicobacter pylori seropositivity and risk of pancreatic cancer. A case-control study. J Natl Cancer Inst 2010;102:502-5.

66. Wadstrom T, Fryzek JP, Demirjan S, Choi JW, Garabrant DH, Nyren $\mathrm{O}$, et al. Antibodies to Helicobacter bilis in patients with pancreatic carcinoma. Helicobacter 2004;9:538.

67. Jesnowski R, Isakson B, Möhrcke C, Berstch C, Bulajic M, Schneider-Brachert W, et al. H. pylori in autoimmune pancreatitis and pancreatic carcinoma. Pancreatology 2010;10:462-6.

68. Nilsson HO, Stenram U, Ihse I, Wadstrom T. Helicobacter species ribosomal DNA in pancreas, stomach and duodenum of pancreatic cancer patients. Word J Gastroenterol 2006;12:3038-43.

69. Trikudanathan G, Philip A, Dasany CA, Baker W. Association between Helicobacter pylori infection and pancreatic cancer. A cumulative Meta-analysis. JOP 2011;12:26-31.

70. Kountouras J, Zavos C, Chatzopoulos D. Autoimmune pancreatitis, Helicobacter pylori infection and apoptosis: A proposed relationship. Pancreas 2005;30:192-3.

71. Bascuñana P, Padrones I, Picazo JJ, Velasco A. Diarrea asociada a Helicobacter pullorum en un niño. Rev Esp Quimioter 2011;24:50-1.
72. Ceelen L, Decostere A, Verschraegen G, Ducatelle R, Haesebrouck F. Prevalence of Helicobacter pullorum among patients with gastrointestinal disease and clinically healthy persons. J Clin Microbiology 2005;43:2984-6.

73. Burnens AP, Stanley J, Morgenstern R, Nicolet J. Gastroenteritis associated with Helicobacter pullorum. Lancet 1994;344:1569-70.

74. Mateos-Muñoz B, Pérez de la Serna J, Ruiz de León A, Serrano Falcón B, Casabona Francés S, Roales Gómez V, et al. Gastroenteritis infecciosa por Helicobacter pullorum. Rev Esp Enferm Dig 2012;104(Supl. I): 84 .

75. Romero S, Archer JR, Hamacher ME, Bologna SM, Schell RF. Case report of an unclassified microaerophilic bacterium associated with gastroenteritis. J Clin Microbiol 1988;26:142-3.

76. Karagin PH, Stenram U, Wadström T, Ljungh A. Helicobacter species and gut bacterial in Meckel's diverticulum and the appendix. World J Gastroenterol 2011;17:4104-8.

77. Bemelman WA, Bosma A, Wiersman PH, Rauws EAJ, Brummelkamp WH. Role of Helicobacter pylori in the pathogenesis of complications of Meckel's diverticula. Eur J Surg 1993;159:171-5.

78. Tuzun A, Polat Z, Kilciler G, Turan I, Kilic A, Ozcan A, et al. Evaluation for Helicobacter pylori in Meckel's diverticulum by using realtime PCR. Dig Dis Sci 2010;55:1969-74.

79. Paredes RM, Muñoz B, Velasco M, González M, Rodríguez J, Martínez $\mathrm{M}$, et al. Implicación del Helicobacter pylori en la etiopatogenia de la apendicitis aguda. Estudios preliminares. Cir Pediatric 2007;70:156-8.

80. Bell SJ, Chisholm A, Owen J, Borriello P, Kamm A. Evaluation of Helicobacter species in inflammatory bowel disease. Aliment Pharmacol Ther 2001;18:481-6.

81. Laharie D, Asencio C, Asselineau J, Bulois P, Bourreile A, Moreau $\mathrm{J}$, et al. Association between entero-hepatic Helicobacter species and Crohn's disease: A prospective cross-sectional study. Aliment Pharmacol Ther 2009;30:283-93.

82. Thomson JM, Hansen R, Berry S, Hope ME, Murray GI, Mukhopadhya I, et al. Enterohepatic Helicobacter in ulcerative colitis: Potential pathogenic entities? PLoS One 6: e17184. Doi:10.137/journal. pone.0017184.

83. Bohr UR, Glasbrenner B, Primus A, Zagoura A, Wex T, Malfertheiner P. Identification of enterohepatic Helicobacter species in patients suffering from inflammatory bowel disease. J Clin Microbil 2004:42:2766-8.

84. Gonçalves A, Pimenta M, Rocha G, Camargos AM, Santos A, Dani $\mathrm{R}$, et al. Helicobacter species in the intestinal mucosa of patients with Ulcerative colitis. J Clin Microbiol 2004;42:384-6.

85. Burich A, Hershberg R, Waggie K, Zeng W, Brabb T, Westrich G, et al Helicobacter induced inflammatory bowel disease in IL-10 and T-cell-deficient mice. Am J Physil Gastrointest Liver Physiol 2001;281:764-78.

86. Young V B, Chien CC, Knox KA, Taylor NS, Schauer DB, Fox JG Cytolethal distending toxin in avian in human isolates of Helicobacter pullorum. J Infect Dis 2000;182:620-3.

87. Wadström T, Hau J, Nilsson I, Ljungh A. Immunoblot analysis as an alternative method to diagnose enterohepatic Helicobacter infections. Helicobacter 2009; 14:172-5.

88. Zanoni RG, Rossi M, Giacomucci D, Sanguinetti V, Manfreda G. Occurrence and antibiotic susceptibility of Helicobacter pullorum from broiler chickens and commercial laying hens in Italy. Int J Food Microbiol 2007;116:168-73.

89. Atabay HI, Corry JE, On SL. Identification of unusual Campylobacter-like isolates from poultry products as Helicobacter pullorum. J Appl Microbiol 1998;84:1017-24.

90. Azevedo NF, Almeida C, Fernandes I, Cerqueira L, Dias S, Keevil CW et al. Survival of gastric and enterohepatic Helicobacter spp. in water: Implications for transmission. Appl Environ Microbiol 2008;74:1805-11.

91. Bascuñana P, Peña I, Picazo JJ, Velasco AC. Sensibilidad antimicrobiana de cepas hipuratos-negativas de Campylobacter spp. y de Helicobacter pullorum aisladas de enfermos con diarrea. Rev Esp Quimioter 2011;24:213-6. 